\title{
The Effectivity of Nutrition Education Booklet on Knowledge, Fast-food Consumption, Calorie Intake, and Body Mass Index in Adolescents
}

\author{
Irfan Said1,2), Anto J.Hadi3), Saskiyanto Manggabarani1), \\ Ida Lestari Tampubolon4), Endang Maryanti3), Agnes Ferusgel5) \\ ${ }^{1)}$ Study Program in Nutrition, Health Institute Helvetia, Indonesia \\ 2)Study Program in Nutrition, School of Health Sciences Pertamedika, Indonesia \\ 3) Masters Program in Public Health, Institut Kesehatan Helvetia,Indonesia \\ 4)Diploma IV of Midwifery, Health Institute Helvetia, Indonesia \\ ${ }^{5)}$ Study Program in Public Health, Health Institute Helvetia,Indonesia
}

Background: The prevalence of adolescent obesity is increasing worldwide with proportions varying from country to country or between geographical regions within a country. The purpose of this study was to determine the effect of nutrition education with booklet media on knowledge, fast food consumption, calorie intake, and body mass index (BMI) in adolescents.

Subjects and Method: This was a quasy experiment with no control group. The study was conducted in Junior high school in Medan, North Sumatera. A sample of 31 adolescents was selected by purposive sampling. The dependent variables were knowledge, fast-food consumption, calorie intake, and BMI. The independent variables were booklet media. Means of knowledge, fast food consumption, calorie intake, and BMI before and after intervention was examined by ttest.

Results: Mean of knowledge after intervention (Mean $=12.90 ; \mathrm{SD}=2.71$ ) was higher than before $(\mathrm{Mean}=8.77 ; \mathrm{SD}=1.54)$ and it was statisticaly significant $(\mathrm{p}<0.001)$. Mean of fast food con- sumption after intervention $($ Mean $=9.48 ; \mathrm{SD}=$ 1.38) was lower than before $(\mathrm{Mean}=10.03 ; \mathrm{SD}=$ 1.16) and it was statistically significant $(p=$ 0.007). Mean of calorie intake after intervention (Mean= 2735.12; $\mathrm{SD}=1999.9$ ) was lower than before (Mean $=2821.09 ; \mathrm{SD}=216.13)$ and it was statistically significant $(\mathrm{p}=0.003)$. BMI after intervention (Mean=26.58; $\mathrm{SD}=2.49$ ) was equal with before intervention (Mean $=26.81 ; \mathrm{SD}=$ 2.49).

Conclusion: Nutrition education with booklet improves knowledge, reduces fast food consumption, and reduce calorie intake.

Keywords: nutrition education, booklets, knowledge, fast food, calorie, body mass index

\section{Correspondence:}

Irfan Said. Study Program in Nutrition, Health Institute Helvetia. Jl. Kapten Sumarsono $107 \mathrm{Me}-$ dan, North Sumatera, Indonesia. Email: Irfansaid1357@gmail.com. Mobile: o85256780839.

\section{Cite this as:}

Said I, Hadi AJ, Manggabarani S, Tampubolon IL, Maryanti E, Ferusgel A (2020). The Effectivity of Nutrition Education Booklet on Knowledge, Fast-food Consumption, Calorie Intake, and Body Mass Index in Adolescents. J Health Promote Behav. 5(1): 11-17. doi: https://doi.org/10.26911/thejhpb.2020.05.01.02

(c) (1) () Journal of Health Promotion and Behavior is licensed under a Creative Commons Attribution-NonCommercial-ShareAlike 4.0 International License.

\section{BACKGROUND}

Obesity is a world health problem that can occur in children to adults, including teenagers. This has become a serious health epidemic problem and a complex phenomenon, estimated to be the fifth leading cause of death at the global level (Al-Hazzaa et al., 2012). The state of obesity that lasts into adulthood increases the risk of degenerative diseases and death. At present social and cultural problems are changing in the world, one of the causes is that economic growth is almost evenly distributed. It also has 
an impact on the change in "taste" of their food, from food choices, to eating patterns, it is increasing from time to time, in this case their tastes are increasingly westernized (Al-Rethaiaa, Fahmy and Al-Shwaiyat, 2010).

Change and increase in nutrition is very high, so obesity becomes a new problem experienced by the world population, especially developing countries today. It is believed that the emergence of obesity in developing countries is likely to create an extraordinary public health burden, because obesity in children and adolescents is closely related to the number of accompanying diseases (Al-Hazzaa et al., 2012).

Current evidence shows that obesity is a condition where multifactorial is influenced by many variables, including genetic, demographic and lifestyle factors. Genetic and demographic variables such as family history of obesity, age, ethnicity and gender cannot be changed. However, obesity related lifestyle factors are often modified. In fact, previous study has shown that obesity is associated with many lifestyle factors, including sedentary behavior, physical activity and unhealthy food choices. Factors related to lifestyle, such as eating habits, sedentary behavior and physical activity, all play an important role in creating an obesogenic environment (Leech et al., 2014).

Increased prevalence of obesity also occurs in developing countries such as Indonesia. Basic health research in 2007 reported that the prevalence of adolescent obesity (aged $\geq 15$ years) was $10.3 \%$. Basic health research data in 2010 which showed an increase in obesity among adults aged $>18$ years was around $11.7 \%$ suffering from obesity (men $7.8 \%$, women $15.5 \%$ ) and around $2.5 \%$ children aged $13-15$ years and $1.4 \%$ of adolescents aged 16-18 years are declared obese. Data on Basic Health Research (Riskesdas) in 2013 showed that nationally the prevalence of obesity in adolescents aged 13-15 years in Indonesia was
$10.8 \%$, consisting of $8.3 \%$ fat and $2.5 \%$ very fat. The results of basic health research show an increase in the prevalence of obesity in adolescents in Indonesia from $1.4 \%$ (2007) to $7.3 \%$ (2013), while for North Sumatera the data of obese adolescents is $13.1 \%$ consisting of $10.9 \%$ fat and $2.7 \%$ very fat. This figure has exceeded the national rate. Based on aninitial survey conducted in August 2018 at primary school 4 Medan, 6 students (18.75\%) were obese from 32 students (1 class) measured.

Children and adolescents who have suffered from obesity tend to remain obese as adults which ultimately affects health conditions. Selection of adolescents (aged 10-18 years) is based on the consideration that adolescents are at high risk of obesity and the incidence of obesity in adolescence (10-18 years) is a good predictor of public health problems and an increased risk of non-communicable diseases and death for all causes in adulthood. Because adolescents are marked as a period of important risk for the development of obesity and its associated consequences, targeting obesity at the threshold of adulthood is very important.

The problem of obesity is experienced by several groups in society, including toddlers, school age children, adolescents, adults and the elderly. The above prevalence of obesity in both children and adolescents and adults is a warning sign for the government and the wider community that obesity and all its implications are a serious threat to the people of Indonesia, especially in big cities (Lwin et al., 2017).

Changes in nutrition in adolescents if not sought improvement will affect the quality of society in the future. The picture of obesity in the present has a big impact on the picture of obesity in the future, so it is necessary to find information and treatment (intervention) about adolescent obesity by way of prevention through education Nutrition education with media booklets. From the results of several studies indicate that an increase in the prevalence 
of over nutrition and obesity in adolescents both in developed countries and in developing countries and in urban and rural areas.

Meanwhile, what factors are the most dominant cause of over nutrition and obesity in adolescents is not known clearly. In addition, many studies that have analyzed the causes of overweight and obesity have been carried out and determined many models of prevention of over nutrition and obesity in adolescents. The purpose of this study was to determine the effect of nutrition education education with booklet media on fast food consumption patterns, calorie intake and weight changes (BMI) in adolescents at Primary High School $4 \mathrm{Me}-$ dan, North Sumatera.

\section{SUBJECTS AND METHOD}

\section{Study Design}

This was a quasy experiment with no control group. This study was conducted at Junior high school in Medan, North Sumatera, from February to September 2019.

\section{Population dan Sample}

The study population were students in Junior high school. A sample of 31 students was selected for this study by purposive sampling.

\section{Study Variables}

The dependent variables were knowledge, fast food consumption, calorie intake, and BMI. The independent variable was booklet media.

\section{Operational Definition of Variables}

Knowledge was the result of knowing students have about nutrition. The measurement scale was continous.

Fast food consumption was a description of the type and frequency of fast food consumed by students. The measurement scale was continous.

Calorie intake was the number of average calorie intake per student. The measurement scale was continous.

Body mass index was nutritional status by measuring students' height and weight and was calculated by body weight $(\mathrm{kg}) /$ Body height $\left(\mathrm{m}^{2}\right)$. The measurement scale was continous.

\section{Study Instruments}

Primary data obtained by direct interviews using a questionnaire that has been prepared previously and to measure height and weight measured using digital scales brand camry and microtoise. Fast food consumption was measured by food frequency questionnaire (FFQ) and a $2 \times 24$ hour food recall form to measure calorie intake before and after the intervention.

\section{Data Analysis}

The analysis used to test the significance of the mean difference of the study variables between before and after the intervention is the t-test.

\section{RESULTS}

A. Sample Characteristics

Table 1 showed sample characteristics.

\begin{tabular}{lcc}
\hline Characteristics & N & \% \\
\hline Gender & & \\
Male & 15 & $48.4 \%$ \\
Female & 16 & $51.6 \%$ \\
Age & & \\
13 Years & 15 & $48.4 \%$ \\
14 Years & 16 & $51.6 \%$ \\
\hline
\end{tabular}

\section{B. The result of bivariate analysis}

Bivariate analysis was performed using paired t-test to examine mean differences in knowledge, fast food consumption, calorie intake, and BMI before and after intervention. The results of bivariate analysis were described in Table 2 
Said et al./ The Effectivity of Nutrition Education Booklet on Knowledge, Fast-food

Table 2. Analysis of Differences in Knowledge, Fast Food Consumption Patterns, Calorie Intake, BMI in the Treatment and Control Groups

\begin{tabular}{lccc}
\hline Variables & Mean & SD & p \\
\hline Knowledge & & & $<0.001$ \\
Pre test & 8.77 & 1.54 & \\
Post test & 12.90 & 2.71 & 0.007 \\
Fast food Consumption & & & \\
Pre test & 10.03 & 1.16 & \\
Post test & 9.48 & 1.38 & 0.003 \\
Calorie Intake & & & \\
Pre test & 2821.09 & 216.13 & \\
Post test & 2735.13 & 199.90 & $<0.001$ \\
BMI & & & \\
Pre test & 26.81 & 2.49 & \\
Post test & 26.58 & 2.49 & \\
\hline
\end{tabular}

Table 2 showed that nutrition education using booklets increased knowledge in students. Mean of knowledge score after intervention (Mean=12.90; $\mathrm{SD}=2.71)$ was higher than before $($ Mean $=8.77 ; \mathrm{SD}=1.54)$ and it was statistically significant ( $\mathrm{p}<0.001)$.

Table 2 showed that nutrition education using booklet decreased fast food consumption in students. Mean of fast food consumption after intervention $(\mathrm{Mean}=9.48 ; \mathrm{SD}=1.38)$ was lower than before $(\mathrm{Mean}=10.03 ; \mathrm{SD}=1.16)$ and it was statistically significant $(\mathrm{p}=0.007)$.

Table 2 showed that nutrition education using booklet decreased calorie intake in students. Mean of calorie intake after intervention (Mean= 2735.12; $\mathrm{SD}=1999.90)$ was lower than before (Mean= 2821.09; $\mathrm{SD}=216.13)$. Table 2 showed that BMI after intervention (Mean= 26.58; $\mathrm{SD}=2.49$ ) was equal with before intervention $($ Mean= 26.81; $\mathrm{SD}=2.49)$.

\section{DISCUSSION}

1. The effect of nutrition education with booklet media on knowledge

A booklet contains information about being overweight adds respondent insight. Often nutritional problems arise due to ignorance of respondents and lack of information about nutrition. The formation of new behaviors from knowledge to stimulation in the form of material about something that will give rise to new knowledge on the respondent and further lead to further responses in the form of action. It can be said, that in the results of this study the level of knowledge of respondents included in the category of know (know) which is interpreted as remembering a material that has been studied before. Included in this level of knowledge is a recall of something specific to the whole material being learned or stimuli that have been received (Arisman, 2008).

The results of the education of nutrition education with the expected booklet media, one of them is weight loss in accordance with the proportion of height and age of the respondent, but in the right way. Overweight in children should not be overcome by limiting eating, because it can eliminate the nutrients needed for the child's growth process. The good solution is to slow down the growth rate of body weight to reach the proportion of weight to normal height by regulating the diet and physical activity of children (Arisman, 2008). This is in line with Widjanarko and Margawati (2015), which stated that there are differences in knowledge (increasing average knowledge) in the treatment group before and after education. 
2. The effect of nutrition education with booklet media on fast food consumption In processing data patterns of fast food consumption is done by giving a score where the higher the score means the fewer respondents consume fast food in their height or the pattern of fast food consumption of the respondent is good, conversely if the respondent has a score a bit means the more respondents consume fast food per week or the respondent has bad food consumption patterns. The pattern of fast food consumption of respondents experienced changes for the better, this may be because respondents already have knowledge of the effects of consuming excessive fast food so that they can change their attitudes to limit consumption of fast food (Harris and Graff, 2012).

One of the causes of overweight in children is the selection of inappropriate types of food, such as high-fat foods. Another factor that might also influence is family consumption habits. High fat consumption is more commonly found by middle and upper class people, this can be caused by their more consumptive and more likely to follow the trend where there are currently many trends that lift high-fat foods such as fast foods which have very low nutritional value (Hansstein et al., 2016; Buckley, 2018).

This study is in line with Albuquerque et al. (2013), Gao et al. (2014), and Vardanjani et al. (2015), which stated that nutritional education has an effect on changes in students' attitudes in limiting fast food.

Educational intervention in nutrition education with booklet media also influences calorie intake, where in this study statistical tests on calorie intake were performed. From each of the variables studied, there is interrelation namely by providing education nutrition education with media booklets can increase respondents' knowledge so that respondents limit the consumption of fast food resulting in decreased calorie intake which ultimately results in a decrease in respondent's BMI. This results is in accordance with Albuquerque et al. (2013) that School is a suitable place for health education, and the children need sufficient knowledge, skills, attitude, and values for their health promotion. On the other hand, the meals consumed during the school hours are one of the important items of nutrition education at schools. Educating adolescents to change consumption behavior in accordance with the rules of nutrition.

Nutrition education with the booklet media also influences the change in respondent's body mass index. This may be due to the education given to the respondent which makes them motivated to lose weight and hope that their body has an ideal body weight. Similar result was reported by Lwin et al. (2017), which stated that there was a significant relationship between broadcast media with both nutrition knowledge and fast food consumption. Greater exposure to broadcast media led to greater nutrition knowledge, but also greater fast food consumption. On the other hand, exposure to other media as well as both parental mediation strategies and children's nutrition knowledge did not have any significant effect on metropolitan children's fast food consumption.

\section{AUTHOR CONTRIBUTION}

Irfan Said collected the data and wrote the manuscript. Anto J. Hadi, Ida Lestari Tampubolon, and Endang Maryanti served in the measurement of body mass index and arranged the booklet media. Saskiyanto Mangg Stephani and Agnes Ferusgel did data analysis and interpreted the results of data analysis.

\section{CONFLICT OF INTEREST}

There was no conflict of interest.

FUNDING AND SPONSORSHIP

The authors would like to thank the Directorate of Research and Community Service, Directorate General of Research and Development Strengthening as Givers of Funds with contract 
Said et al./ The Effectivity of Nutrition Education Booklet on Knowledge, Fast-food

number T/135/ L1.3.1/PT.01.03/2019 on April $25,2019$.

\section{ACKNOWLEDGEMIENT}

We would like to thank the Directorate of Research and Community Service, Directorate General of Research and Development Strengthening and Junior high school in Medan which giving permission to conduct the study.

\section{REFERENCE}

Albuquerque AG, Pontes CM, Osório MM (2013). Knowledge of educators and dieticians on food and nutrition education in the school environment. Revista de Nutrição. 2(3): 291-300. http://dx.doi.org/10.1590/S141552732013000300004.

Al-Hazzaa H, Abahussain NA, Al-Sobayel HI, Qahwaji DM, Musaiger AO (2012). Lifestyle factors associated with overweight and obesity among Saudi adolescents. BMC Public Health. 12: 354. doi: 10.1186/1471-2458-12-354.

Al-Rethaiaa AS, Fahmy AEA, Al-Shwaiyat NM (2010). Obesity and eating habits among college students in Saudi Arabia: A cross sectional study. Nutrition Journal. doi: 10.1186/1475-2891-9-39.

Arisman MB (2008). Obesitas, diabetes mellitus, dan dislipidemia. Jakarta: EGC.

Buckley J (2018). Availability of high-fat foods might drive the obesity epidemic. Nat Rev Endocrinol 14: 574-575. doi:10.1038/s41574-018-0084-3.

Gao Y, Huang Y, Zhang Y, Liu F, Feng CX, Liu T, Li C, Lin D (2014). Evaluation of fast food behavior in pre-school children and parents following a one-year intervention with nutrition education. Int $\mathrm{J}$ Environ Res Public Health. 11(7): 6780-6790. https://dx.doi.org/10.3390\%2Fijerph11o706780

Handarbeny WR, Mahmudiono $\mathrm{T}$ (2017). Pengaruh pendidikan gizi berbasis theory of planned behavior untuk mempromosikan pembatasan konsumsi fast food pada siswi. (The Effect of Nutrition Education Based on Theory of Planned Behavior to Promote the Limitation of Fast Food Consumption in Schoolgirls), Amerta Nutrition. 1(4): 351-360. http://dx.doi.org/10.20473/amnt.v1i4.2017.351-360

Hansstein FV, Hong Y, Di C (2016). The relationship between new media exposure and fast food consumption among Chinese children and adolescents in school: a rural-urban comparison. Global Health Promotion. 24(3): 40-48. https://doi.org/10.1177\%2F1757975915602187.

Leech RM, McNaughton SA, Timperio A (2014). The clustering of diet, physical activity and sedentary behavior in children and adolescents: A review. International Journal of Behavioral Nutrition and Physical Activity. 11(4): 1-9. doi: 10.1186/1479-5868-11-4.

Lwin MO, Malik S, Ridwan H, Au CSS (2017). Media exposure and parental mediation on fast-food consumption among children in metropolitan and suburban Indonesia. Asia Pac J Clin Nut. 26(5):899905.

Harris JL, Graff SK (2012). Protecting young people from junk food advertising: Implications of psychological research for first amendment law. 102(2): 214-222. https://dx.doi.org/10.2105\%2FAJPH.2O11.300328 .

Nurmasyita, Widjanarko B, Margawati A (2015). Pengaruh intervensi pendidikan gizi terhadap peningkatan pengetahuan gizi, perubahan asupan zat gizi dan indeks massa tubuh remaja kelebihan berat badan (Effects of nutrition education interventions on increasing nutritional knowledge, changes in nutrient intake and body mass index of overweight ado- 
Said et al./ The Effectivity of Nutrition Education Booklet on Knowledge, Fast-food

lescents). Jurnal Gizi Indonesia. 4(1): 3847 doi: 10.1016/j.bbrc.2015.10.023.

Vardanjani AE, Reisi M, Javadzade H, Pour ZG, Tavassoli E (2015). The Effect of nutrition education on knowledge, atti- tude, and performance about junk food consumption among students of female primary schools. J Educ Health Promot. 4: 53. doi: 10.4103/2277-9531.162349 